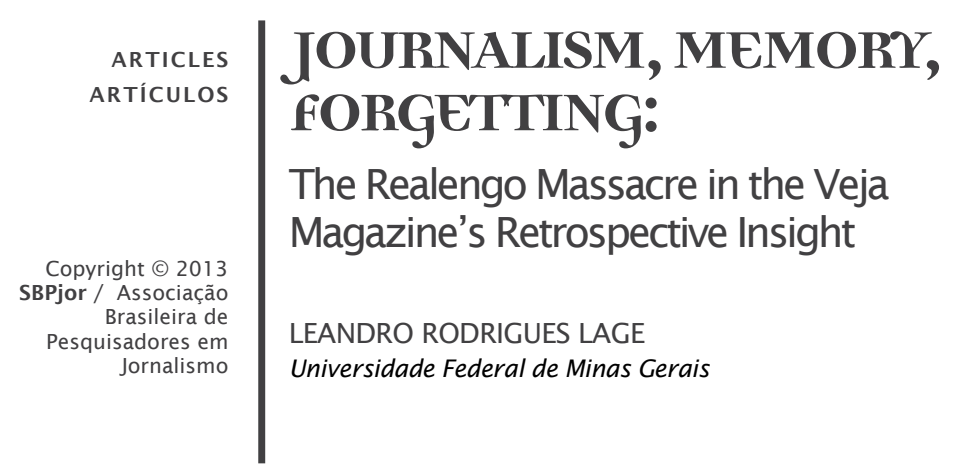

ABSTRACT - This paper discusses the tensions between memory and forgetting, which are commonly found in journalistic narratives. The goal is to understand, in the light of the concepts of "duty of memory" and "abuse of forgetting", as delineated by Ricoeur, the contradictions evidenced by the work with memory as carried out by jour-nalists. For that purpose, Veja Magazine's coverage of the Realengo Massacre episode is used as a reference, as it unfolded in two issues of the magazine: December 28, 2011, when the magazine presented the 2011 Retrospective, and dedicated a report to the trag-edy that took place in Rio de Janeiro; and January 4, 2012, when Veja published the letter written by a teacher who had witnessed the bloodbath and criticized Veja's memory/forgetting thus stressing that journalistic work of memory. Ultimately, journal-ism is approached as a mediating sphere of memory and is therefore subject to the di-lemmas of reminiscence concerning the organization of memory in face of the texture of the events experience. Keywords: Memory. Forgetting. Narrative. Event.

\title{
JORNALISMO, MEMÓRIA, ESQUECIMENTO: o massacre de Realengo na retrospectiva de Veja
}

RESUMO - O trabalho versa sobre tensões entre memória e esquecimento presentes nas narrativas jornalísticas. Busca-se compreender, à luz dos conceitos de "dever de memó-ria" e "abuso de esquecimento", tais como abordados por Ricoeur, contradições eviden-ciadas pelo trabalho de memória operado pelo jornalismo. Para tanto, observa-se episódio da cobertura do massacre de Realengo feita pela revista Veja que se desdobrou em duas edições: a de 28 de dezembro de 2011 , em que o periódico apresenta a Retrospectiva de 2011 e dedica uma reportagem à tragédia ocorrida no Rio de Janeiro; e a de 4 de janeiro de 2012, na qual a revista publica a carta de uma professora, testemunha do assassínio, que critica o gesto de lembrança/esquecimento de Veja, tensionando aquele trabalho jornalístico de memória. Aborda-se, ao final, o jornalismo como instância mediadora de memória e, por isso, sujeita aos dilemas da reminiscência, relativos à tessitura da memória frente à textura da experiência dos acontecimentos.

Palavras-chave: Memória. Esquecimento. Narrativa. Acontecimento.

\section{PERIODISMO, MEMORIA, OLVIDO: la masacre de Realengo en la retrospectiva de Veja}

RESUMEN - El artículo trata de las tensiones entre la memoria y el olvido presentes en los relatos periodísticos. El objetivo es entender, a la luz de los conceptos de "deber de memoria" y "abuso de olvido" de Ricoeur, las contradicciones evidenciadas por el trabajo de memoria practicado por el periodismo. Para ello, se examina un episodio de la cobertura de la masacre de Realengo realizado por la revista Veja, que se desdobló en dos ediciones: la del 28 de diciembre de 2011 , cuando la revista presentó la retrospectiva de 2011 y dedicó un reportaje a la tragedia ocurrida en Río de Janeiro; y la del 4 de enero de 2012 en la cual la revista publicó una carta de una maestra, testigo del asesinato, que criticaba el gesto de recuerdo/olvido de Veja, tensando así el trabajo periodístico de memoria. Finalmente, se aborda el periodismo como instancia mediadora de la memoria y, por lo tanto, sujeta a los dilemas de la reminiscencia relativos a la tesitura de la memoria frente a la textura de la experiencia de los acontecimientos.

Palabras clave: Memoria. Olvido. Narrativa. Acontecimiento. 
Thanks to the work of memory, completed by that of mourning, each of us has the duty not to forget, but to recall the past, as painful as it maybe, under the guidance of a pacified memory

P. Ricoeur (2003)

\section{INTRODUCTION}

On the morning of April 7, 2011, young Wellington Menezes de Oliveira entered Tasso da Silveira County School, in the Rio de Janeiro neighborhood of Realengo, and became the protagonist of the worst school massacre ever catalogued in Brazil in terms of the number of victims. Carrying two handguns, Oliveira walked into one of the classrooms and shot the students. Twelve of them died, and another twelve were wounded. A policeman was found nearby and called for help; with a single shot, he stopped the assassin, who then committed suicide. That tragic morning had not finished yet; an avalanche of information took over the news for a long time.

The main motivation for the development of the present paper, however, was an episode in Veja Magazine's coverage of the Realengo Massacre. The episode proved to be problematic in the light of the relations of temporality articulated in journalistic narratives, and mainly because of the tensions between memory and forgetfulness that arise in this type of reporting. This tension is at the same time invoked by the journalistic entities themselves, aware of their work with memory, and revealed within the scope of the journalistic work of reporting the events. The relevant case was unfolded in two issues of the magazine: on December 28, 2011, the weekly magazine published its 2011 Retrospective and dedicated a report to the tragedy that took place in Rio de Janeiro; in the following issue, on January 4, 2012, the magazine published a letter written by teacher Leila D'Angelo, a witness of the assault.

The problematic episode caught our attention in the course of a research survey entitled Poéticas jornalísticas do acontecimento (Journalistic Poetics of Events); we then endeavored to obtain a comprehension of the Realengo Massacre's narrative texture, as executed by Veja magazine and Folha de S.Paulo newspaper. We were, at the time, 
interested in elements of journalistic narratives and, above all, in the role causal texture plays in the weaving of stories from such events. Although they were not part of our initial concern, the issues related to memory and forgetfulness revealed in Veja's coverage drew our attention, given the contradictions that arose within the context of "work of memory" and of forgetfulness, which we will be addressing here - executed by narrative journalism, beyond the mere invoking of the past as memories.

Within the scope of media studies, in general, stating that the media agents represent true memory spaces has become a cliché, which does not mean considering them only as depositaries of memories, but above all, understanding them as memory building and dispute grounds (SILVERSTONE, 2002; BARBOSA, 2006; RIBEIRO; BRASILIENSE, 2007; BABOLANÇA, 2011 ; CARVALHO; LAGE, 2012). It seems necessary, before we go on, to distinguish between media discourse, which arrogates to itself the role of a collective memory hallmark, and the insight that acknowledges the media's place as an instance of memory's re-significance, especially within a social-historical context marked by a "culture of memories" (HUYSSEN, 2000)'

On the other hand, a framework of compulsion for memory requires special attention to one of its most important dimensions: forgetfulness. "For the more we are asked to remember in the wake of the information explosion and the marketing of memory, the more we seem to be in danger of forgetting and the stronger the need to forget" (HUYSSEN, 2000, p. 28). It thus becomes essential, while assessing the media's exercising of memory, to take forgetfulness into account, as an integrated part of reminiscence. We will have an opportunity later, following in the wake of Ricoeur (2004), to perceive forgetfulness not only as a memory gap, but as a condition of memory, with all the risks and tensions that are related to that dialectic.

So far, we have only referred to the media in the most generic manner, but what about journalism? In a cultural environment where memory becomes unrestricted, how can this tricky relation between memory and forgetfulness be disclosed in journalistic narratives?

In this paper, we will limit the discussion to problem-issues brought about by journalistic memory narratives associated to the aforementioned episode. At first, we will observe the retrospective narrative published by the Veja Magazine in the light of the Ricoeurian concepts of "duty of memory" and "abuse of forgetting", in an attempt to comprehend the magazine's effort as a type of response to the need to recall such a notable event while, at the same time, voicing a certain 
wish for forgetfulness in relation to the massacre's protagonist. In the sequence, the protest of a witness of the Realengo Massacre is presented, considering this act as a new defense of the "duty of memory" brought about by the event.

Ultimately, beyond establishing a mere media criticism of Veja, or even construing it under the ambivalent insight of good or poor journalistic coverage, we hope to understand this important journalistic work as an activity where memory and forgetfulness are strategically used and organized in a relation that is more complex than that of a simple presentification of a past event.

\title{
1 VEJA'S RETROSPECTIVE ISSUE: BETWEEN MEMORY AND FORGETTING
}

In its December 28, 2011 issue, Veja published its year-end retrospective issue, where the magazine elected and reviewed the major events of the previous 12 months. Two pages were dedicated to the Realengo Massacre. These pages show a background image of a photo taken by Wellington Menezes de Oliveira himself, before the massacre, in which the murderer was aiming one of the handguns he used in the bloodbath against his own head. The picture was found by the police in the assassin's computer a few days after the crime. Next to the image, which entirely covers both pages, a short, but eloquent text under the headline Retrato da loucura (A Portrait of Insanity) summarizes the event:

\begin{abstract}
From the classic plots of bloodbath authors, the Realengo murderer emulated more than the costumes. The terrifying self-portrait, taken little before he killed twelve children in a Rio neighborhood school, revealed another cliché of that kind of criminals - their concern with posterity, a reflex of their belief that they are special beings. Before they cut their ultimate bond with sanity, they commonly record their own image, statements and messages in the Internet, considering that to be a legacy to the humanity that treated them with an unfair indifference. This is how the Realengo murderer acted; he killed himself after the massacre, and nobody recalls his name anymore. In the school where the assault took place, the classroom where most of the murdered boys and girls used to study was demolished, and a new hall, leading to a new classroom, was built there. In it, there is a tile wall where the students, invited to decorate it as they pleased, filled the tiles with phrases about how they miss their late schoolmates (Free translation of VEJA, 2011 , p. 103).
\end{abstract}

As Veja brought the massacre to its retrospective issue, it embraced the effort of recalling an event that was incontestably striking, from the point of view of collective experience (VAZ, 2012)2. It is doubtful that the magazine, with that issue, was responding to a paradigmatic expectation on behalf of its readers, so much as to a 
marketing perspective, considering that its direct competitors, IstoÉ and Época Magazines, also published their retrospectives. The mnemonic issue, however, although strongly bound to rituals within the sphere of journalistic practices, may also be interpreted as a kind of prevention against the forgetfulness that followed. As stated by Babo-Lança (2011, p. 83), retrospectives allow the media to reveal themselves, as these are "recognition, construction and transmission mechanisms of a collective memory that intervenes in our relation with the event and with its senses, as well as in our recognition of the past and of history" (BABO-LANÇA, 2011 , p. 83). It is not only a marketing strategy, but also the very effort of the media to maintain itself as a space for memory and events that must be remembered.

Our interest here is to focus on the interpretation of the work of memory that Veja attempted, with all its nuances and contradictions. Upon re-telling the story of the Realengo Massacre, the magazine in a way responds to a need for memory, operating an effective intervention in our recognition of that event. As Babo-Lança (2011) puts it, we would like to think of the work of memory carried out by journalism, in its inflection as the "duty of memory". In Veja's case, that duty is shown both as a concern with an event that claims to be remembered, and with its evoking the past to make sure it does not repeat itself.

According to Ricoeur (2004), who mainly discusses historical narratives, the duty of memory inherent to any historical condition requires a narrative counter-effect. "The duty of memory is the duty to do justice, through memories, to one other than the self" (RICOEUR, 2004 , p. 89). Narrating something that happened in the past is generally understood as an act of respect for the victims, removed in this way from the shades of forgetfulness. If memory and past times are no longer the strict concerns of the historical narratives, ethical dilemmas of reminiscence, such as the duty of memory have become a constant in other narrative spheres.

Veja's case seems to be a specific one, as it reminds us of the victims and suffering, but it also condemns the crime and derogates the author. The retrospective work carried out by the magazine inevitably brings about an ambiguity between homage and derogation. An event that cannot be forgotten, that must be celebrated (using the word's most formal meaning); at the same time, a deplorable event, whose memory imposes a trauma to be overcome. Pursuant to this need to remember, we understand, based on Ricoeur, that the act of narrating is a judicious response to the duty of memory: 


\begin{abstract}
Extracting the exemplary value from traumatic memories, it is justice that turns memory into a project; and it is this same project of justice that gives the form of the future and of the imperative to the duty of memory. We can then suggest that the duty of memory considered as the imperative of justice is projected as a third term onto the point of intersection of the work of mourning and the work of memory (RICOEUR, 2004, p. 88).
\end{abstract}

For the philosopher, the duty of memory is an extension of the pair mourn/memory towards ethics. Discussing memory as imperative, as an obligation, is immediately invoking the least of two commitments: one to the past, which is worthy of being remembered, especially in the case of traumas from which we take lessons; and the other with the future, precisely because the memories and the examples they provide allows us to work to ensure the past does not to repeat itself. Within this context, narratives occupy a position of prevalence, serving as the means to configure memory, and therefore crisscrossed by the values that accompany them.

The exemplary value taken by Veja from that image and the memory of the event seem to be unique and unfortunate: the Realengo murderer is one more criminal that entered the long list of young and insane assassins who expect the bloodbaths they foster to become a glorious legacy. But the magazine's work could not avoid at least two contradictions. The first one regards the will to forgetfulness, manifested in a contradictory manner in that retrospective narrative. Under the argument that the magazine was not an accessory to the murderer's obvious eagerness for visibility, Veja refuses to write his name, Wellington Menezes de Oliveira. With the reader's permission, we will reproduce a small stretch of the report transcribed above: "This is how the Realengo murderer acted; he killed himself after the massacre, and nobody recalls his name anymore." (VEJA, 2011 , p. 103, our highlights).

By refusing to mention the murderer's name, the magazine proposes, and furthermore prompts us to forgetfulness. Recalling Wellington Menezes de Oliveira would imply, in Veja's view, a certain journalistic connivance with the murderer's act. Justice for the victims, a typical trait of the duty of memory, would accrue, in a contradictory manner, from the forgetfulness of the executioner, not from invoking the memory of the event. Therefore, there would be something seemingly accidental amidst what was to be remembered in the narratives. Memory and forgetfulness arise as symmetric elements, integrating the same action, in the pursuit of justice by means of memory. The (un)balance of this action is provided by the narrative that configures the memory. The 
texture of the journalistic report determines whatever is to be recalled and, symmetrically, whatever is to be forgotten.

In addition to the memory configuring effect, the narrative undertakes, according to Ricoeur (2004), the mediator's role, which hinders us from noticing an intended completeness of memory, imposing forgetfulness to a certain extent. "If one cannot recall everything, neither can one recount everything. The idea of an exhaustive narrative is a performatively impossible idea. The narrative necessarily contains a selective dimension" (RICOEUR, 2004, p. 448). In the same vein, one acknowledges that no narrative whatsoever is able to fully recall a fact, yet that the narrative itself also fulfills its role in memory organization and forgetfulness, by corollary. Hence, once conditioned to the narrative texture and its selective dimension, memory arises as the one that may be handled, in the sense that it is subject to handling strategies operated by the texture dimension.

Veja's contradictory act leads us to invoke another important Ricoeurian concept, in opposition to the duty of memory; it is what the philosopher calls an abuse of forgetting. Ricoeur (2004) mentions three types of abuses of forgetting which are also, by symmetry, abuses of memory ${ }^{3}$ : the first one, known as blocked memory, relates to blocking and push-backs and is therefore far too individual and psychopathological for our purposes; the second one, that interests us most, is the so-called manipulated memory, related to the intentional subduedness of memory; and the third one, too broad for our purposes, is the commanded forgetting, recognized as amnesty.

Manipulated memory seems to be the category that best fits into the comprehension of how Veja develops its narrative. Setting up the forgetfulness strategy mobilized by the magazine in the surroundings of what is understood as manipulated memory implies, however, all the risks of the semantic load of the term "manipulation." Nevertheless, if also construed as a type of handling, such modality of abuse of forgetting helps us think of the strategic use of memory. Handling memory, as done by Veja, fits much better into what we would call, as Ricoeur (2004) does, active forgetfulness, which attempt to obliterate whatever is manifest in the event - the "insane" murderer from Realengo, in this specific case -, than into an arbitrary subduedness of memory.

Forgetting, in the form of absence of memory, is used by Veja as a kind of "remedy against evil", alluding to Todorov (2009). The past is invoked, hoping it will not repeat itself, and expecting us to learn lessons from it. Forgetting the murderer's name, Wellington Menezes de Oliveira, 
can, in this sense, be a deterrent for those who are prone to imitation.

However, if the story told by Veja and the exclusion of the author's name is to dissimulate forgetfulness, a further issue arises: to what extent does the intent to "learn with the past" justify the insertion of forgetfulness into the pursuit of memory?

On top of this thin line that splits just memory from forgetfulness, Todorov (2009) presents, if not a satisfactory response, at least another means of managing the problem we face: "What if we were going about it the wrong way and the problem resided not in recourse to memory and to the past but in the specific role that we want to make them play and in the conclusions that we draw from them?" (TODOROV, 2009, p. 449). What matters is precisely the ambition to take lessons and to make them last in a game of imposed rules, where invoking memory and forgetfulness rejects radical approaches that may impose any rigidness to it. In other words, it becomes problematic when forgetfulness is used to profit from lessons learned, running the risk of not effectively facing the problem through the use of memory.

The forgetfulness strategies, as well as their abuses, become evident, according to Ricoeur (2004), only with a review of the narrative configurations. "The strategies of forgetting are directly grafted upon this work of configuration: one can always recount differently, by eliminating, by shifting the emphasis, by recasting the protagonists of the action in a different light along with the outlines of the action" (RICOEUR, 2004, p. 448). In the method of tailoring their report, Veja reveals what is convenient for the magazine to remember or to forget, which ends up backing the comprehension of that act as an abusive one, as the magazine sees itself tending to impose forgetting, despite the persistence of the trauma, of the impact of the relevant event.

Two contradictions have been mentioned above regarding Veja's attitude. The second derives precisely from the first. Alongside the magazine's wish to forget the Realengo murderer's name lies the very method of construction of that narrative, with its several textualities. Veja engraves the puissant picture of Wellington Menezes de Oliveira on two pages entirely dedicated to recall the event. The report's very headline reveals the emphasis of the story: Retrato da loucura (A Portrait of Insanity). In addition to the eloquence of the image of the murderer aiming his handgun against himself and that of the emphatic title, another aspect seems contradictory: in favor of the protagonist of the narrative, the Realengo Massacre victims also had their names forgotten in Veja's most significant act of memory about what had happened (our 
expectations that the magazine would publish a report on the event after a whole year had elapsed, in April, 2012, was frustrated; that absence may be understood both as forgetfulness of the event and as a corollary of the game of temporalities present in journalism).

Abuse of forgetting? Insufficient memory? The memory narrative tailored by Veja is better understood if we observe how it unfolded itself, which runs against the manipulation of memory, in its most urgent meaning, at the same time ratifying, to a certain extent, an insight from the idea of abuse of forgetting.

\title{
2 THE DUTY OF MEMORY AND FORGETFULNESS MANAGEMENT
}

As a development of the retrospective issue, the following issue of Veja published, in the "Reader" Section, a letter signed by teacher Leila D'Angelo, a witness of the Realengo Massacre and one of the characters that had figured in the event's journalistic coverage. Against the exhortation to forgetfulness carried by the magazine, and in a movement of protest against the intended visibility of the murderer, the teacher interposes the traumatic memory that persecutes the witnesses that were closest to the event.

\begin{abstract}
I am a teacher at the Tasso da Silveira School, in the neighborhood of Realengo, in Rio, that was struck by a massacre on the 7th of April. I was in the first classroom the assassin entered, and killed three children. I admit I was already expecting to see the unfortunate episode at the school in the Retrospective 2011 , since it was an unprecedented and indelible fact. As I read the report "A Portrait of Insanity" (December 28, I was surprised with the statement that nobody remembers the assassin's name any longer. All the people involved do remember that name, day after day. The teachers remember it even more, as our lives were turned upside down because of this episode. We lost dear pupils, and our peace, as we are constantly harassed by some of the family members of the murdered children. We, the teachers, still suffer with the acts of insane Wellington Menezes de Oliveira (free translation of D'ANGELO, 2012, p. 24).
\end{abstract}

The letter written by teacher Leila D'Angelo is clearly a manifest, a protest against the deletion suggested by Veja, whatever the reason for the acts may have been. In that sense, forgetfulness again occupies a position symmetrically opposite to that of memory. In its retrospective narration, the magazine overlaps the will to forgetfulness to the duty of memory, however justifiable and paradoxical it may be. D'Angelo's response, endorsed by the magazine, exposes contradictions of the management of memory carried out by Veja, which suggests a new attempt to achieve the merits of the duty of memory. One can acknowledge, after 
all, that the fact that the magazine published D'Angelo's letter, totally directed to Veja's coverage, holds a significant value of memory, in the sense of doing justice to the victims and witnesses - and we will likewise understand such attitude as being part of the journalistic process in its reflexive concern and self-criticism.

Forgetfulness again shows up in Veja in its most elementary sense: as an enemy of memory. "In the first instance and on the whole, forgetting is experienced as an attack on the reliability of memory. An attack, a weakness, a gap. In this regard memory defines itself, at least in the first instance, as a struggle against forgetting" (RICOEUR, 2004, p. 413). In its retrospective narrative of the massacre, the magazine proposes a kind of amnesia, which ends up, no matter how timely and just it may be, ignoring the continuous dimension of impression-affection of the events as something it allows and expects and as memory. As mentioned by D'Angelo, those who witnessed the massacre do remember it very well, every single day.

By purging the murderer's name from the narrative exercise of memory, Veja applies an inaccurate use of memory as a remedy against evil, which is distant, professedly and paradoxically ignored (although thoroughly exposed by the assassin's image aiming the handgun at himself). Inaccurate, because, as evidenced in the massacre witness's reaction, breaking out and doing justice by means of memory depend on the handling, that is, on the very narrative configuration of what is recalled and what is forgotten. For Todorov (2009), the opposition exerted by memory against evil in the narrative plan does not take place within a framework of dereliction, but in one of coping:

\footnotetext{
The memory of the past will serve no purpose if used to build an impassable wall between evil and us, identifying exclusively with irreproachable heroes and innocent victims and driving the agents of evil outside the confines of humankind. [...]

Once the crime has been committed, we can only console the victims, not really help them anymore. But we can have an effect on the criminals, on those who committed crimes in the past, so that they do not repeat their crimes, and on future criminals (TODOROV, 2009, p. 461).
}

The evil that lies in the past, in this sense, would have to be coped with by means of memories, of memory narratives. "The memory of the past could help us in this enterprise of taming evil, provided that we keep in mind that good and evil flow from the same source and that in the world's best narratives they are not neatly divided" (TODOROV, 2009, p. 462). Veja's effort is presented, as a matter of fact, as an incubation of such evil, which could only be domesticated when manifest and evident. 
On the other hand, when the floor is granted to those who were present at the event, the magazine does not try to bypass the tensions caused by the duty of memory, by the will to do justice through memories.

In this scenario, how is the problematic duty of forgetfulness ${ }^{4}$ setup? What is the plan that holds the impossibility of recalling everything, either due to the limits of the narrative, or by the trauma invoked while remembering?

The answer, obviously incomplete, seems to lie in the strategies of memory usage. The tension between the will of forgetfulness and the duty of memory, revealed by Veja upon covering the Realengo Massacre, seems to have its origins, above all, in a contradictory memory management. The massacre narrative's configuration in the magazine's retrospective issue, collated to the response of one of the witnesses of the terrible event and published in the following issue of the magazine, may be construed as an abuse of forgetting, both for what it leaves behind the assassin's name - and for the method it uses to do so - exploring the murderer's image, and leaving the victims in the background.

Going back to Ricoeur, whose philosophical design in Memory, history, forgetting (2004) focuses mainly on the potential reconciled memory, that is, in the potential justice and forgiveness deriving from memory and forgetfulness, we could state that the abuse of forgetting places itself as an obstacle to such intent. Forgetfulness, as seen before, would lead to justice if it did not seek to overcome evil, yet to go back or describe it in order to domesticate it. Forgetfulness, for the author, could not therefore arise in the form of a duty, of an imperative action.

\begin{abstract}
What, then, is there to say about the alleged duty of forgetting? Besides the fact that any projection into the future in the imperative mood is just as incongruous in the case of forgetting as it was for memory, a command of this sort would amount to a commanded amnesia. If this were to happen - and unfortunately nothing stands in the way of crossing the thin line of demarcation separating amnesty from amnesia - private and collective memory would be deprived of the salutary identity crisis that permits a lucid reappropriation of the past and of its traumatic charge (RICOEUR, 2004, p. 456).
\end{abstract}

Forgetfulness thus hinders the just perception of the past when it arises as a commandment, as an imposition. Hence, it is no longer a condition for memory but becomes commanded forgetting; an attempt against memory.

Given the paradoxical way Veja develops its narrative about the Realengo Massacre in the retrospective issue, as well as its unfolding in the following issue, Veja's act does not seem to be peremptory, as if 
perpetrating forgetfulness. As a response to the first attempt to recall the massacre (forgetting the name of its author), the magazine passes the floor to the witnesses, allowing them to build their own memories, or to defend a memory. For Ricoeur (2004), the condition for a reconciled memory is a likewise reconciled forgetfulness. "If a form of forgetting could then be legitimately invoked, it would not be as a duty to silence evil but to state it in a pacified mode, without anger" (RICOEUR, 2004, p. 456). Considering the teacher's response to Veja's stance, it is possible to notice that, for those who survived the massacre, memory continues and requests further narration.

\section{BETWEEN DUTY AND ABUSE: A DIFFICULT BALANCE}

The dilemma evidenced by the episode in Veja for the journalistic work of memory seems to be related, above all, to its strategic use. At the same time, while handling a type of "duty of memory" established by the experience of specific events - especially traumatic ones - and incorporated by the very logic of journalistic production that expects to recall everything, there is always a risk of incurring in "abuses of memory/ forgetting", that is, excessively forgetting or recalling.

From Veja's retrospective episode, we may at least infer that journalism, as a space for memories, is also a scene for the organization and management of memory and forgetfulness. It seems this organization is under scrutiny, not only of the readers but also of those who actually witnessed the memorable events - and who, nevertheless, depend on a certain opening to face the memory narratives in coherence with what we earlier referred to as memory building and dispute grounds.

Ultimately, this insight of Veja's retrospective shows us that, rather than being an obsession with memories, where the journalistic media agencies struggle and help to establish their narratives, forgetfulness may arise both as the opposite of memory and as a condition in its own right. The magazine could not recall all the facts about the event, but this only shows the need to select what ought to be recalled or not. Furthermore, in the episode covered by Veja, one notices that issues act upon this selection that override the constant concern with objectiveness while recovering the past. By invoking memory, the magazine's narrative fosters problems of an ethical nature that help us expand the range of possibilities of seizing and stressing the place occupied by memories in such narratives - for instance, raising issues on the limits of memory and forgetfulness. 
On the other hand, unfolding that coverage of the Realengo Massacre, confronted with the context where a "culture of memory" prevails, seems to enhance the importance of the journalistic memory narratives, so that justice is done by means of memory; but it also calls our attention to the fact that we cannot remember nor forget in any way. Within that context, we would risk stating that the journalistic work of memory, as a rule, may be an issue concerning both the past invoked and the narrative activity itself, namely, configuration of memory, and subject to conflicts of meanings and traumatic burdens surrounding whatever is remembered; and, therefore not always forgettable.

\section{NOTES}

1 According to Huyssen (2000), dissemination of the "culture of memory" concerns, above all, obsession with the past, evidenced by the growing trade and disclosure of memory. It is worth highlighting, however, that the author questions the idea that the "culture of memory" is a strictly contemporaneous phenomenon, in fact considering it a recent form of voicing a historical concern with memory and with forgetfulness, undergoing specific inflections in each nation or continent.

2 Vaz (2012) offers an interesting statement about the emergency context of that event within the sphere of the media, thoroughly overtaking the national news, and hence practicing unquestionable intervention on the experience, from both a collective and social perspective.

3 The expression "abuse of memory" comes from an essay by T. Todorov, whose title is exactly Les abus de la mé-moire (2000), and is borrowed by Ricoeur (2004) to deal with the issues that, in the original text, relate more precisely to the contemporary bustle for celebrations. In short, to relate to the unconditional compliment to memory that leads to both enthusiasm and rage. For Ricoeur, abuses of memory are necessarily abuses of forgetting, both problematic features in a potential range of just memory - and just forgetfulness.

4 It is worthy to remind that, for Ricoeur (2004), the only place where memory and forgetfulness cannot find symmetry is in the "duty" plan. From an ethical point of view, it becomes problematic to think of a duty of forgetfulness. This is why the philosopher's project proceeds towards reconciled memory and forgetfulness (under the aegis of a "duty of memory"). 


\section{REFERENCES}

BABO-LANÇA, Isabel. Configuração mediática dos acontecimentos do ano. Revista Caleidoscópio. v. 1, n. 10. Lisboa, 2011. p. 73-84.

BARBOSA, Marialva. Mídias e usos do passado: o esquecimento e o futuro. Revista Galáxia. v. 6, n. 12. São Paulo: PUC, 2006. Available at: < http:// revistas.pucsp.br/index.php/galaxia/article/view/1458/922>. Accessed on: 18 jul. 2012.

CARVALHO, Carlos Alberto de; LAGE, Leandro. As relações entre jornalismo e temporalidade para além da urgência implicada na factualidade. In: Anais da ALAIC 2012 - Congreso Latinoamericano de Investigadores en Comunicación. Available at: < http://alaic2012.comunicacion.edu.uy/sites/default/files/as_ relacoes_entre_o_jornalismo_e_temporalidade_carlos_carvalho_e_leandro_ lage_0.pdf $>$. Accessed on: 18 jul. 2012.

D'ANGELO, Leila. Leitor. Veja. São Paulo: Editora Abril, 04 jan. 2012. p. 24.

HUYSSEN, Andreas. Present Pasts: Media, Politics, Amnesia. Public Culture, v. 12, n. 1, 2000. p. 21-38.

RIBEIRO, Ana Paula Goulart; BRASILIENSE, Danielle Ramos. Memória e narrativa jornalística. In: RIBEIRO, Ana Paula Goulart; FERREIRA, Lúcia Maria Alves. Mídia e Memória - A produção de sentidos nos meios de comunicação. Rio de Janeiro: Mauad X, 2007. p. 219-235.

RICOEUR, Paul. Memory, history, forgetting. Chicago: The University of Chicago Press, 2004.

RICOEUR, P. Memory, history, oblivion. Lecture presented at the International Conference "Haunting Memories? History in Europe after Authoritarianism ", held on March 8, 2003, in Budapest, Hungary. Available at: <http://www. fondsricoeur.fr/photo/Budapest\%202003\%20texte\%20Angl\%20\%20(2).pdf>.

SILVERSTONE, Roger. Por que estudar a mídia? São Paulo: Loyola, 2002.

TODOROV, Tzvetan. Memory as Remedy for Evil. Journal of International Criminal Justice, v. 7, 2009. p. 447-462.

TODOROV, Tzvetan. Los abusos de la memoria. Buenos Aires: Paidós, 2000.

VAZ, Paulo Bernardo. Na onda dos acontecimentos cotidianos. In: FRANÇA, Vera Regina Veiga; OLIVEIRA, Luciana (Orgs.). Acontecimento: reverberações. 1 ed. Belo Horizonte: Autêntica, 2012.

VEJA. Retrato da loucura. São Paulo: Editora Abril, 28 dez. 2011 . p. 102-103. 
Leandro Rodrigues Lage Doctoral student in Communication at the Federal University of Minas Gerais (UFMG), Minas Gerais, Belo Horizonte, Brazil. E-mail: leandrorlage@gmail.com.

RECEIVED ON: 29/04/2013 |APPROVED ON: 07/07/2013 
JOURNALISM, MEMORY, FORGETTING 